\title{
Causes and consequences of algal blooms in Loch Logan, an urban impoundment
}

\author{
AT Vos and JC Roos* \\ Centre for Environmental Management, University of the Free State, PO Box 339, Bloemfontein 9300, South Africa
}

\begin{abstract}
Loch Logan is situated at the "Waterfront" in the city centre of Bloemfontein. During the rainy season it collects stormwater from the surrounding catchment areas as well as other urban runoff water. During summer, Loch Logan frequently experiences algal blooms. The system can be classified as eutrophic due to high dissolved reactive phosphate $\left(\mathrm{PO}_{4}-\mathrm{P}\right)$ and chlorophyll- $a$ (Chl- $a$ ) concentrations. Nitrogen is probably the limiting factor to algal growth. The consequences of the eutrophication are algal blooms, oxygen depletion, fish kills, excessive macrophyte growth, odour problems and extreme oscillations occur in physical and chemical parameters.
\end{abstract}

Keywords: impoundment, nutrients, nitrogen, phosphorus, oxygen, $\mathrm{pH}$, bacteria, chlorophyll- $a$, algae.

\section{Introduction}

Impoundments within South African towns and cities are not recent developments. For example, Zoo Lake in Johannesburg is a man-made impoundment that was built during the first decade of the $20^{\text {th }}$ century. Additionally, natural water bodies, such as pans and vleis, have been gradually surrounded by urban development in certain cities (e.g. North End Lake, Port Elizabeth) and these have also become important aesthetic and recreational attractions for urban residents. More recently, commercial and recreational developments have increasingly been built with impoundments as their central feature, e.g. Bruma Lake and the Brightwater Commons (formerly the Randburg Waterfront) in Johannesburg (Freeman et al., 2000).

Local authorities provide urban impoundments primarily for recreational purposes, stormwater control, and to improve the psychological well-being of city dwellers by relieving the pressure of modern urban life (Wiechers et al., 1996).

Water quality problems associated with urban impoundments are also not something new, e.g. Jan Smuts Dam in Brakpan has a documented record of such problems stretching back to 1940 . Unfortunately many urban impoundments act as receptacles for upstream waste, resulting in silted up impoundments. The impoundments' enrichment with plant nutrients (referred to as eutrophication) often leads to the associated growth of undesirable algae and water plants, increased health risks due to bacteriological contamination; and aesthetic problems such as unsightly algal scum, floating debris and malodours (Freeman et al., 2000) - see Photograph 1.

Because of these problems, what should be a public asset can turn into a liability. Even more seriously, it can pose a health risk. Such water quality problems also tend to be accentuated in urban areas where man's activities are wide-ranging, densely

\footnotetext{
* To whom all correspondence should be addressed.

前 +2751 401 2265/2863; fax: +2751 4012629 ;

e-mail: RoosJC.sci@mail.uovs.ac.za

Received 12 January 2004; accepted in revised form 17 March 2005.
}

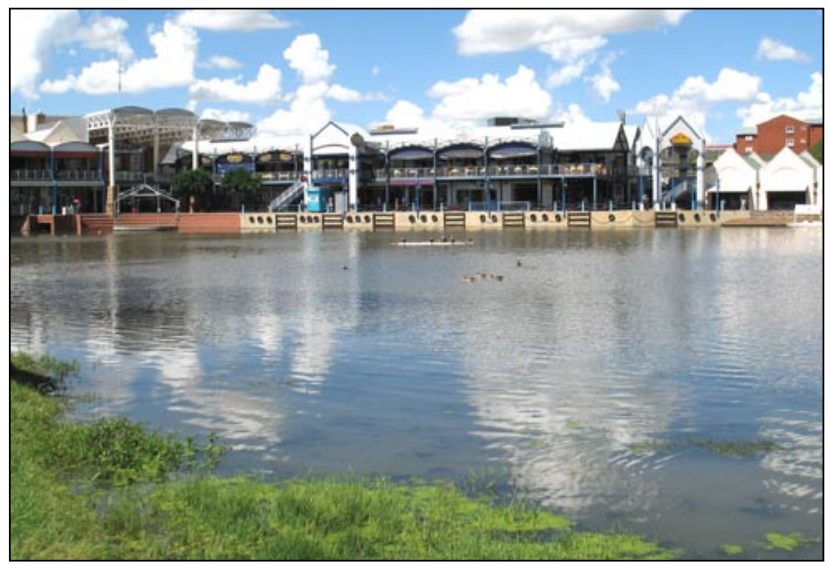

Photograph 1

Intrusion of Kikuyu grass and undesirable growth of Lemna gibba (duckweed) and Azolla filiculoides (red water fern) in Loch Logan, Bloemfontein

concentrated and frequently culminate in the generation of numerous waste streams, which may enter watercourses (Freeman et al., 2000).

Natural processes of rainfall, erosion and solution, evaporation, and sedimentation regulate the chemical composition of natural waters (Horne and Goldman, 1994). Climate affects water quality in a number of ways. For instance, temperature determines the rate and extent of various chemical interactions. Mean annual rainfall and seasonal differences in rainfall; determine the amount of water flowing in rivers or entering wetlands and lakes at different times of the year. Therefore, these factors also determine the degree of dilution of natural chemical constituents and of pollutants. Evaporation, on the other hand, concentrates dissolved substances in the water.

It has been well known even before 1960 that urban stormwater discharge may contain high concentrations of a wide variety of potentially toxic chemicals. However, the chemical forms in which those contaminants exist and the duration of exposure that aquatic life would receive from such discharges are such 


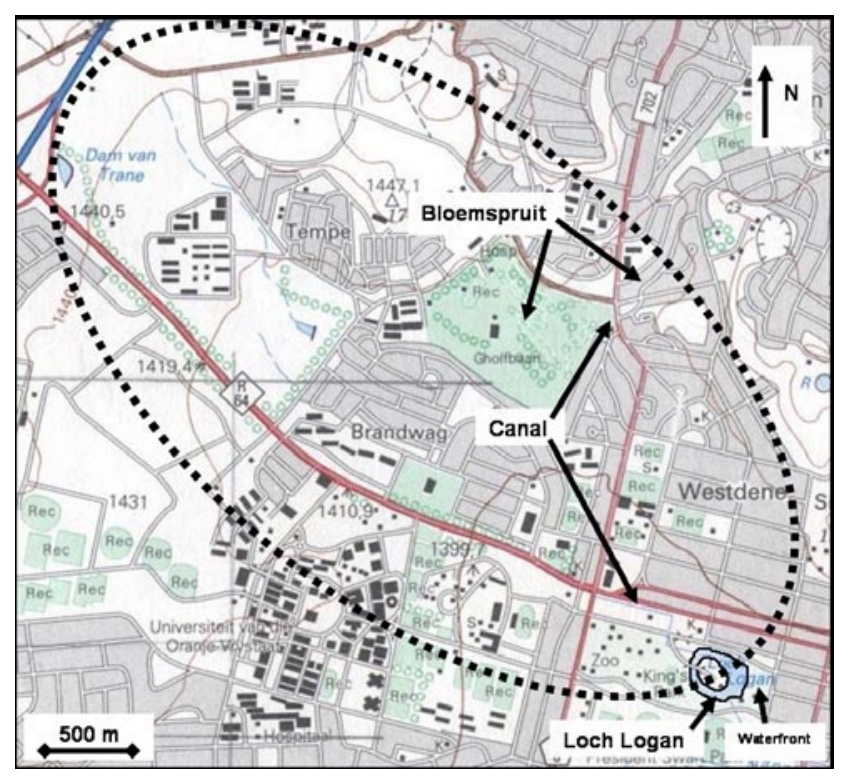

Map 1

1:50 000 Topographic, Map Sheet no: 2926AA Bloemfontein (see scale inserted on map), showing approximate catchment area, squared dotted (-..) oval, and location of Loch Logan $\left(29^{\circ}\right.$ $06^{\prime} 845^{\prime \prime} S$ and $\left.26^{\circ} 12^{\prime} 505^{\prime \prime} E\right)$

that it would be expected to be indeed rare that contaminants in urban stormwater from residential and most commercial, industrial, and construction site areas would cause an impairment of the designated beneficial uses of water bodies (Lee and JonesLee, 1993).

Loch Logan, an impoundment in the centre of Bloemfontein experienced eutrophication problems during 1999 as well as and during the study period 2000 to 2001 reported in this paper. The causes and associated consequences were investigated.

\section{Materials and methods}

\section{Study site}

Loch Logan was built in one of the canal systems of the Bloemspruit, in the Westdene area near the city centre of Bloemfontein. It is this canal system that feeds Loch Logan with runoff water collected from the urban areas $\left(\sim 16 \times 10^{6} \mathrm{~m}^{2}\right)$. In $1997 \mathrm{a}$ "waterfront" was developed on the banks of Loch Logan.

Loch Logan (grid reference: $29^{\circ} 06^{\prime} 845^{\prime \prime} \mathrm{S}$ and $26^{\circ} 12^{\prime} 505^{\prime \prime}$ E) is located in a summer rainfall area, which receives between 500 to $700 \mathrm{~mm} / \mathrm{a}$, half of which is through thunderstorms (Koning, 1998). However, $57.9 \mathrm{~mm}$ was recorded for May 1999. The Loch Logan area received an average of $558.9 \mathrm{~mm} / \mathrm{a}$ over the past 10 years; however, in 2000 and 2001 it received respectively $644.8 \mathrm{~mm}$ and $761.2 \mathrm{~mm}$ (SA Weather Service, 2001).

The runoff water from the catchment (Map 1) is canalised to Loch Logan, and enters the lake at its north-western side. Eventually the Bloemspruit flows into the Renosterspruit (about $12 \mathrm{~km}$ downstream from Loch Logan), which joins the Modder River near Glen Agricultural College above Glen Barrage.

Loch Logan has a volume of about $95000 \mathrm{~m}^{3}$, an area of approximately 4.2 ha, (the island excluded) and a mean depth of $2.26 \mathrm{~m}$ (maximum depth $=3.8 \mathrm{~m}$ ). In the middle of Loch Logan is an island that divides the water mass into two almost equal arms. The shoreline length of Loch Logan is approximately $1053 \mathrm{~m}$, and that of the island is $560 \mathrm{~m}$. The dam wall of the

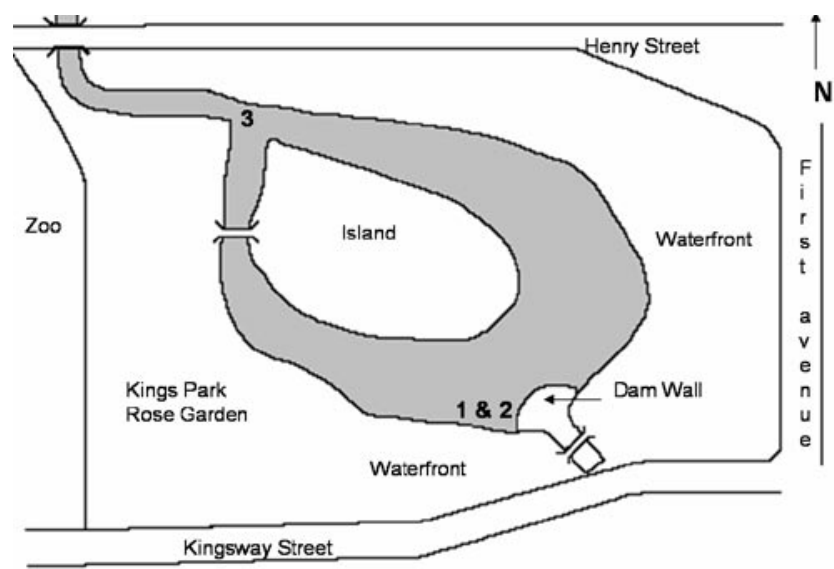

Figure 1

Map of Loch Logan with sampling sites: (1) Dam Wall Surface, (2) Dam Wall Bottom and (3) Inflow

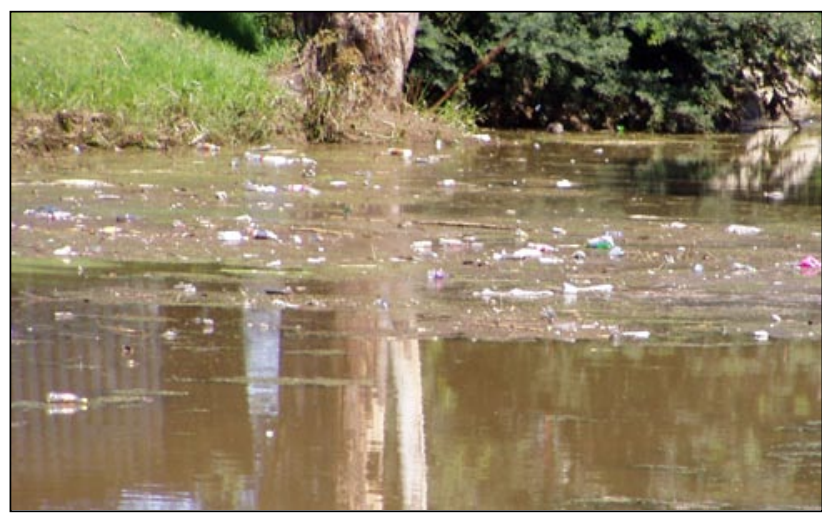

Photograph 2

Organic material and litter at Loch Logan's inflow after a rainstorm

impoundment is situated on the south-eastern side of Loch Logan (Fig. 1).

A broad strip (1 to $3 \mathrm{~m}$ ) of the water surface, along the edges and island, is covered with red fern (Azolla filiculoides) and duckweed (Lemna gibba), which indicate eutrophic conditions. Near the shore Elodea spp. grow below the water surface (Photograph 1).

The upper reaches of the canal that flows into Loch Logan are polluted by the waste from urban and homeless people settlements, the latter using the canal as a latrine facility. Particularly after the rain wastes are washed into Loch Logan, which makes this an ideal environment for bacterial growth (Photograph 2).

\section{Methods}

The water sampling sites were situated at the dam wall, (1) surface water and (2) bottom water, and at the canal inflow (3) (Fig. 1). The water was sampled once a week (on Mondays) from June to December 2000 for this study, although the total study period extended from January 2000 to May 2001.

Water temperature $\left({ }^{\circ} \mathrm{C}\right)$, concentration of dissolved oxygen $(\mathrm{mg} / \ell)$ and percentage of saturation were measured with an YSI Model 58 dissolved oxygen meter and were done in situ. Turbidity, a measurement of the concentration of suspended solids (organic, inorganic and biological material in the water) (clarity), was determined with an Aqua Lytic Turbidimeter AL 1000 and 
is expressed as nephelometric turbidity unit (NTU).

To determine the $\mathrm{pH}$ and redox potential of the water the HANNA HI 9023 microcomputer $\mathrm{pH}$ meter was used and in situ measurements were made.

Ammonium-nitrogen $\left(\mathrm{NH}_{4}-\mathrm{N}\right)$ was determined by using the phenate method as described in Standard Methods (1995). Absorbency was read at $640 \mathrm{~nm}$. (All absorbencies were determined with the Varian Cary $3 \mathrm{UV}$-visible spectrophotometer whereafter the unknown concentrations were determined by plotting it against a standard curve of known concentrations for each of the analyses.)

Nitrate-nitrogen $\left(\mathrm{NO}_{3}-\mathrm{N}\right)$ was determined by using the brucine method as described in Jenkins and Medsker, 1963. Absorbency was read at $410 \mathrm{~nm}$.

Dissolved reactive ortho-phosphate $\left(\mathrm{PO}_{4}-\mathrm{P}\right)$ (an indication of eutrophication) was determined by using the stannous chloride method as described in Standard Methods (1995). Absorbency was read at $690 \mathrm{~nm}$.

Mangaung Municipality performed the bacteriological analyses.

Chlorophyll- $a$ was measured using a modified methanol method described by Sartory and Grobbelaar (1984). The dominant algal species were identified with an inverted Zeiss light microscope after fixation with formaldehyde (final concentration of $2 \%$ ) and placed in a sedimentation chamber for at least $24 \mathrm{~h}$.

\section{Results}

The early spring rains started during September (Fig. 2) with the maximum rainfall $(90 \mathrm{~mm})$ received during the summer (December 2000). The total rainfall from June to December was $253.1 \mathrm{~mm}$, which was $10 \mathrm{~mm}$ below the average of the June to December rainfall for 1995 to 2000.

The surface $\mathrm{NO}_{3}-\mathrm{N}$ concentrations in Loch Logan at the Dam Wall (DW) were low during the winter, but increased significantly during September (to $277.5 \mu \mathrm{g} / \ell$ ) after the first spring rain (Fig. 3). The $\mathrm{NO}_{3}-\mathrm{N}$ concentrations in the $\mathrm{DW}$ bottom water layer were on average $20 \%$ higher than the DW surface concentrations, probably because of sediment release and decomposition. The seasonal pattern of the inflow looked the same as that of the surface, with an increase in September.

The ammonium nitrogen $\left(\mathrm{NH}_{4}-\mathrm{N}\right)$ concentration showed a lag of one month to the rainfall data (Fig. 4), because the organic material that is washed into Loch Logan first has to decompose for $\mathrm{NH}_{4}-\mathrm{N}$ to be released (Photograph 2). The $\mathrm{NH}_{4}-\mathrm{N}$ was low, less than $100 \mu \mathrm{g} / \ell$ at the surface and inflow, and less than 150 $\mu \mathrm{g} / \ell$ at the bottom, during the winter months (Jun to Aug). After the first spring rain the $\mathrm{NH}_{4}-\mathrm{N}$ concentration increased rapidly during October 2000 to an average of $555 \mu \mathrm{g} / \ell$ at the DW surface, $663 \mu \mathrm{g} / \ell$ at the DW bottom, and $462 \mu \mathrm{g} / \ell$ at the inflow, after which the $\mathrm{NH}_{4}-\mathrm{N}$ concentration decreased towards December 2000 .

The dissolved inorganic nitrogen (DIN) average concentration for the study period was $318 \mu \mathrm{g} / \ell$ (Table 1 ). The DIN concentration increased from June to October 2000, whereafter it decreased towards December 2000.

The reactive ortho-phosphate $\left(\mathrm{PO}_{4}-\mathrm{P}\right)$ concentrations (Fig. 5) were less than $60 \mu \mathrm{g} / \ell$ at the DW bottom and inflow during the winter, whilst at the DW surface the maximum $\mathrm{PO}_{4}-\mathrm{P}$ concentration for the winter was $150 \mu \mathrm{g} / \ell$. During the spring rain the overall $\mathrm{PO}_{4}-\mathrm{P}$ concentration increased significantly with an average of $144 \mu \mathrm{g} / \ell$ at the DW surface, $178 \mu \mathrm{g} / \ell$ at the DW bottom, and $143 \mu \mathrm{g} / \ell$ at the inflow. In general this indicated a

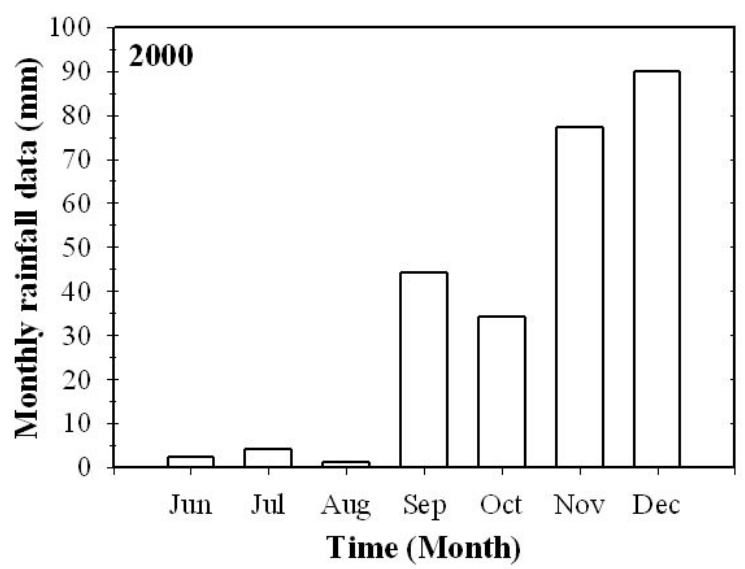

Figure 2

The total monthly rainfall data from June to December 2000 in Bloemfontein (SA Weather Service, 2001)

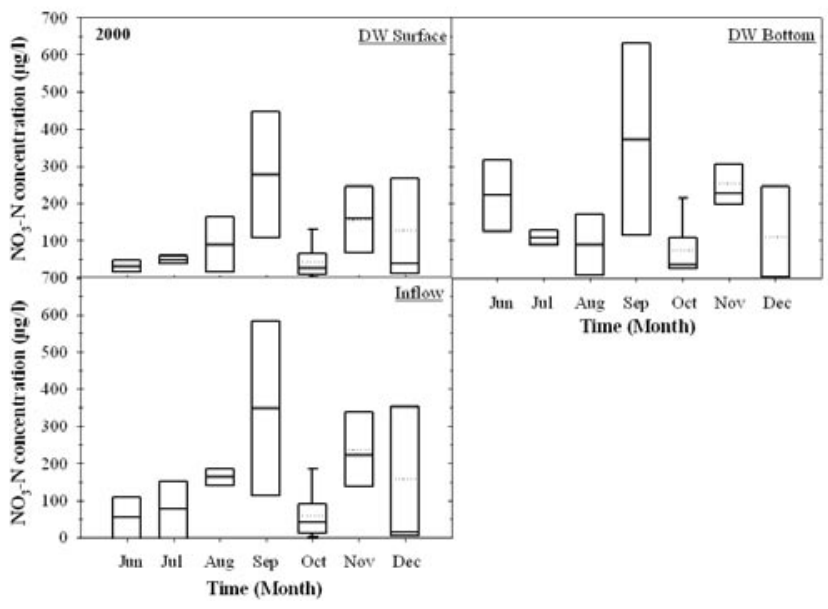

Figure 3

Box plots of the nitrate-nitrogen $\left(\mathrm{NO}_{3}-\mathrm{N}\right)$ concentration $(\mu \mathrm{g} / \ell)$ in Loch Logan at the sampling sites over the study period (June to December 2000). The dotted line indicates the mean values and the solid line the median ( $D W=$ dam wall).

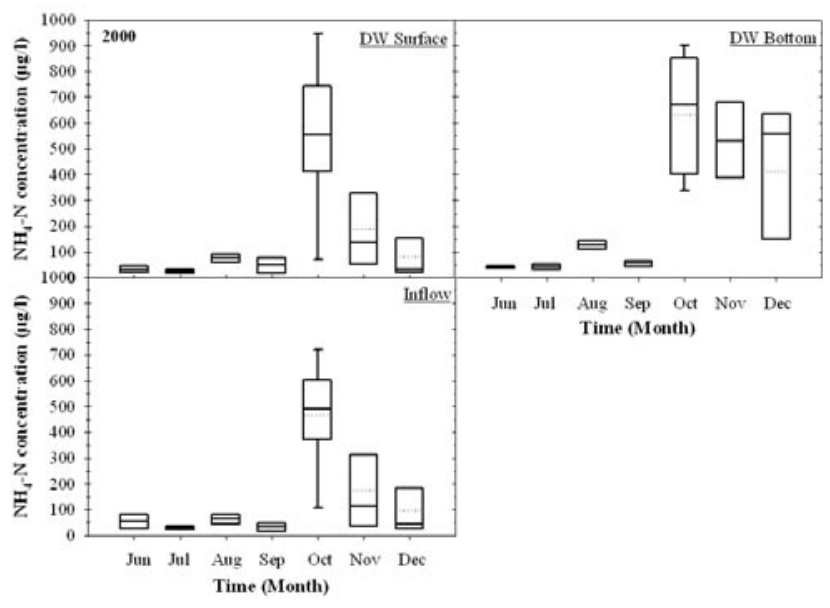

Figure 4

Box plots of the ammonium-nitrogen $\left(\mathrm{NH}_{4}-\mathrm{N}\right)$ concentration $(\mu \mathrm{g} / \ell)$ in Loch Logan at the sampling sites over the study period (June to December 2000). The dotted line indicates the mean values and the solid line the median. 
low $\mathrm{PO}_{4}-\mathrm{P}$ concentration during the winter and a high concentration during the summer.

The overall dissolved inorganic phosphates (DIP; the DIP in this case is equal to the $\mathrm{PO}_{4}-\mathrm{P}$ ) concentrations from June to December 2000 are shown in Table 2, as well as the corresponding DIN: DIP ratios for the same period. The average $\mathrm{N}$ : $\mathrm{P}$ ratio for the study period was 4.3 .

The dissolved oxygen $\left(\mathrm{O}_{2}\right)$ concentration (Fig. 6) at the DW surface and at the inflow followed the same pattern with high concentrations during the winter (averages of $8.0 \mathrm{mg} / \ell$ and 8.5 $\mathrm{mg} / \ell$ respectively) that decreased sharply during the spring rain (September) and increased again towards December. At the DW bottom, the $\mathrm{O}_{2}$ concentrations decreased after the winter and stayed low during the summer $(<2 \mathrm{mg} / \ell)$.

\begin{tabular}{|c|c|c|c|c|c|c|c|c|}
\hline \multicolumn{9}{|c|}{$\begin{array}{c}\text { TABLE } 1 \\
\left.\text { The mean dissolved inorganic nitrogen ( } \mathrm{DIN}=\mathrm{NH}_{4}-\mathrm{N}+\mathrm{NO}_{3}-\mathrm{N}\right) \\
\text { concentration from June to December } 2000 \text { of all the sites }\end{array}$} \\
\hline & Jun & Jul & Aug & Sep & Oct & Nov & Dec & Ave \\
\hline $\mathrm{NH}_{4}-\mathrm{N}(\mu \mathrm{g} / \ell)$ & 43 & 33 & 89 & 46 & 552 & 300 & 197 & 180 \\
\hline $\mathrm{NO}_{3}-\mathrm{N}(\mu \mathrm{g} / \ell)$ & 103 & 78 & 114 & 333 & 59 & 215 & 133 & 148 \\
\hline $\operatorname{DIN}(\mu \mathrm{g} / \ell)$ & 146 & 111 & 203 & 379 & 611 & 515 & 330 & 328 \\
\hline
\end{tabular}

\begin{tabular}{l} 
The mean dissolved inorganic phosphates (DIP = PO $-\mathbf{- P}$ ) \\
concentrations and N: P ratios from June to December 2000 \\
of all the sites \\
\hline \\
\hline
\end{tabular}

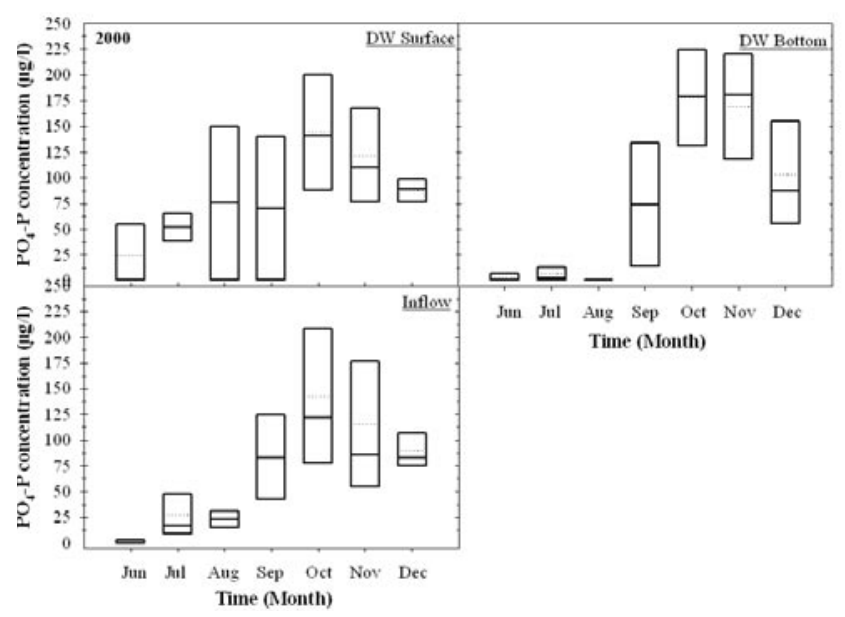

Figure 5

Box plots of the reactive ortho-phosphate $\left(\mathrm{PO}_{4}-\mathrm{P}\right)$ concentration $(\mu \mathrm{g} / \ell)$ in Loch Logan at the sampling sites over the study period (June to December 2000). The dotted line indicates the mean values and the solid line the median.

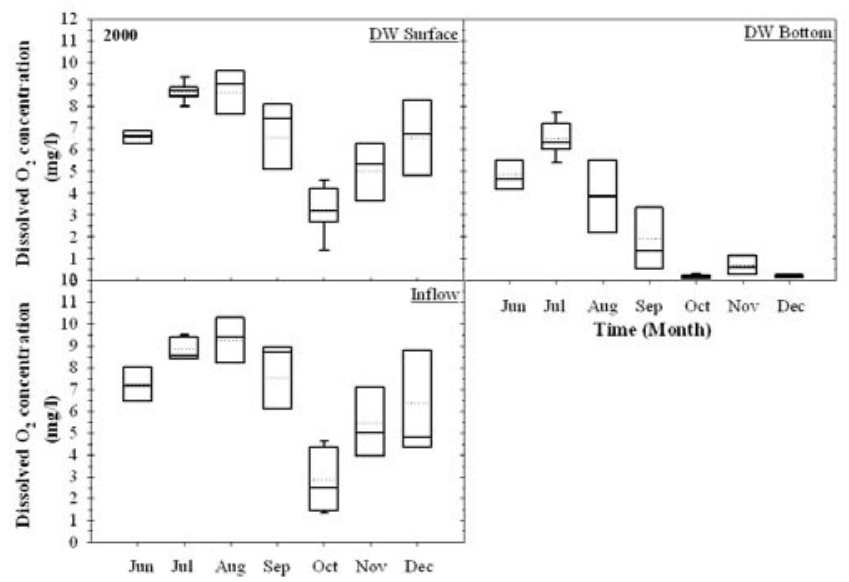

Figure 6

Box plots of the dissolved oxygen $\left(\mathrm{O}_{2}\right)$ concentration $(\mathrm{mg} / \mathrm{l})$ in Loch Logan at the sampling sites over the study period (June to December 2000). The dotted line indicates the mean values and the solid line the median.
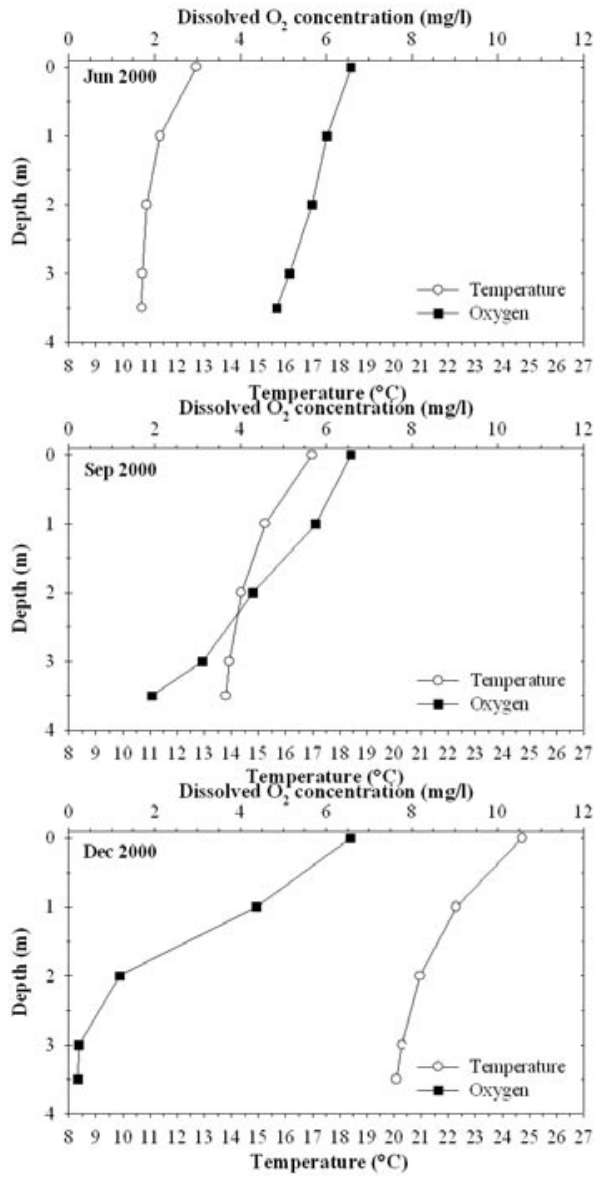

Figure 7

The dissolved oxygen $\left(\mathrm{O}_{2}\right)$ concentration $(\mathrm{mg} / \mathrm{\ell})$ and temperature $\left({ }^{\circ} \mathrm{C}\right)$ depth profiles of June, September and December 2000 at the Dam Wall

The $\mathrm{O}_{2}$ and temperature depth profiles (Fig. 7) of June, September and December 2000 at the DW showed how the $\mathrm{O}_{2}$ concentration changed during the different seasons. During winter (June), the $\mathrm{O}_{2}$ concentration was high and there was a slight decrease in the $\mathrm{O}_{2}$ concentration (6.58 to $4.85 \mathrm{mg} / \ell$ ) from the surface to the bottom. During spring (September) the $\mathrm{O}_{2}$ concentration was still fairly high, but started to decrease at the bottom, while during the summer (December) the $\mathrm{O}_{2}$ concentration was also high at the surface, but decreased rapidly from the surface $(6.57 \mathrm{mg} / \ell)$ to the bottom $(0.21 \mathrm{mg} / \ell)$. 


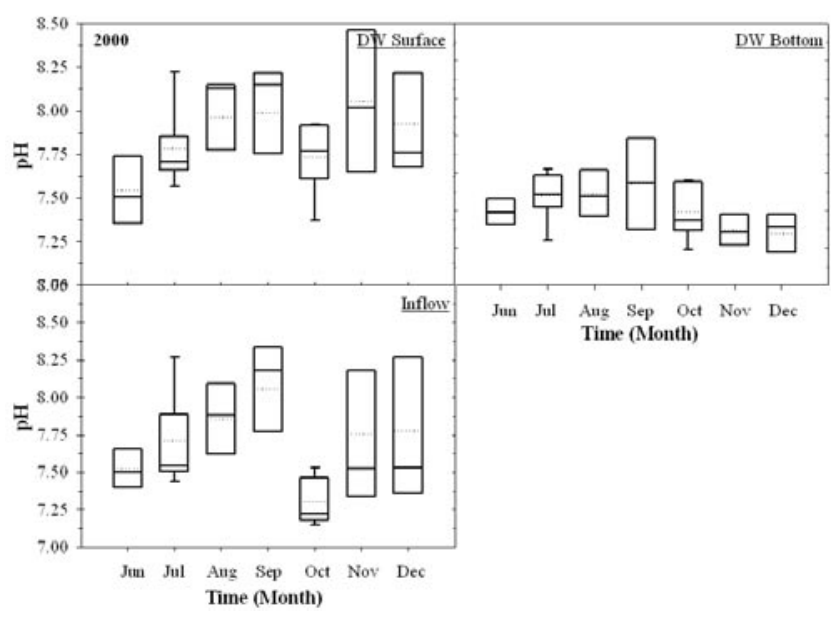

Figure 8

Box plots of the $\mathrm{pH}$ in Loch Logan at the sampling sites over the study period (June to December 2000). The dotted line indicates the mean values and the solid line the median.

The same pattern can be observed for the temperature (Fig. 7) profile. During the winter the water temperature did not change much throughout the water column, while in the summer the temperature is much lower at the bottom than at the surface (a difference of about $4^{\circ} \mathrm{C}$ ). This indicates poor mixing of the water column.

The $\mathrm{pH}$ levels (Fig. 8) followed a similar pattern as that of the $\mathrm{O}_{2}$ concentration, i.e., high in winter and low in summer. A positive trend $\left(\mathrm{r}^{2}=0.24 ; \mathrm{p}<0.01\right)$ between $\mathrm{O}_{2}$ concentration and $\mathrm{pH}$, of the DW surface water, can be seen in Fig. 9.

The bacterial count (total coliforms and Escherichia coli) were on average very low during the winter months, the total coliforms were 1028 cells $/ 100 \mathrm{~m} \ell$ and the E. coli 50 cells $/ 100$ $\mathrm{m} \ell$ (Table 3). However, after the first rain in spring (September) the total coliforms increased to 170000 cells $/ 100 \mathrm{~m} \ell$ and the $E$. coli to 10000 cells $/ 100 \mathrm{~m} \ell$. This increase in bacterial count after the rain continued throughout the study period.

\begin{tabular}{|l|c|c|}
\hline \multicolumn{3}{|c|}{ TABLE 3 } \\
$\begin{array}{c}\text { The total coliforms and Escherichia coli } \\
\text { in Loch Logan for the study period from } \\
\text { June to December } \mathbf{2 0 0 0}\end{array}$ \\
\hline Date & $\begin{array}{c}\text { Total coliforms } \\
\text { (per 100 me) }\end{array}$ & $\begin{array}{c}\text { E. coli } \\
\text { (per 100 me) }\end{array}$ \\
\hline $06 / 06 / 2000$ & 1800 & 140 \\
\hline $04 / 07 / 2000$ & 600 & 35 \\
\hline $08 / 08 / 2000$ & 110 & 14 \\
\hline $29 / 08 / 2000$ & 1600 & 8 \\
\hline $19 / 09 / 2000$ & 170000 & 10000 \\
\hline $26 / 09 / 2000$ & 1800 & 100 \\
\hline $06 / 10 / 2000$ & 40000 & 4300 \\
\hline $09 / 10 / 2000$ & 700 & 100 \\
\hline $24 / 10 / 2000$ & 3100 & 2400 \\
\hline $21 / 11 / 2000$ & 1800 & 350 \\
\hline $19 / 12 / 2000$ & 1600 & 600 \\
\hline
\end{tabular}

The chlorophyll- $a$ (Chl- $a$ ) concentrations (Fig. 10) were high during the study period, especially at the inflow $(\max =\mu \mathrm{g} / \ell)$. In October the surface Chl- $a$ decreased after the rain to an average of $19 \mu \mathrm{g} / \ell$, after which it increased again. The same pattern can be observed at the inflow data. The average algal composition of June, September and December is shown in Table 4.

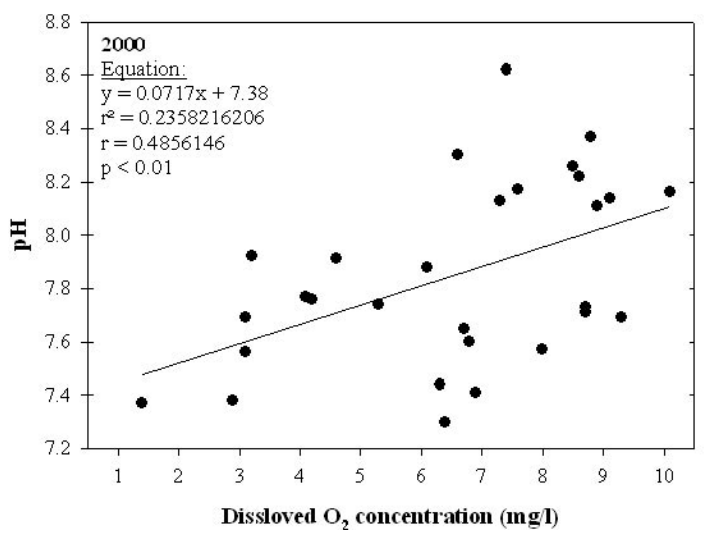

Figure 9

Relationship between $\mathrm{pH}$ and dissolved oxygen $\left(\mathrm{O}_{2}\right)$ concentration (mg/l) at the Dam Wall Surface over the study period (June to December 2000).

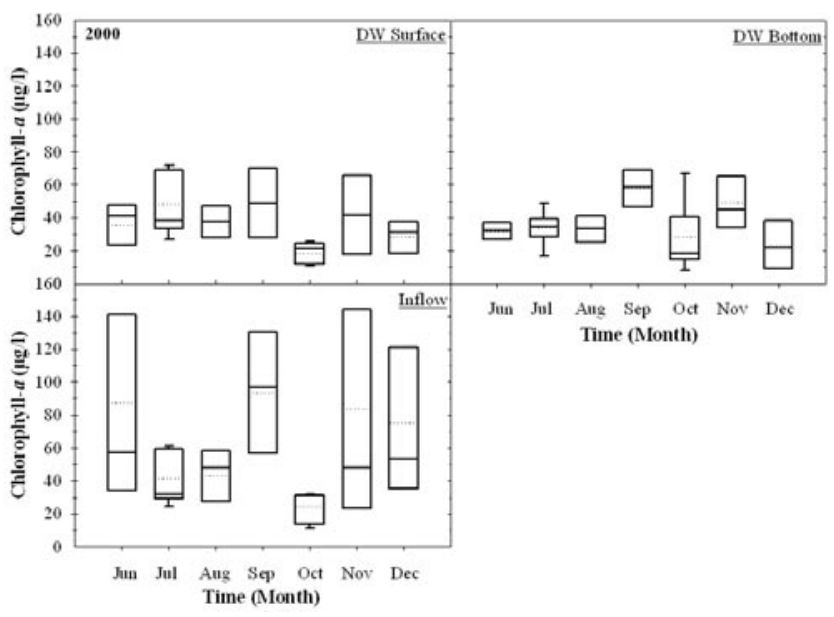

Figure 10

Box plots of the chlorophyll-a (Chl-a) concentration $(\mu \mathrm{g} / \mathrm{l})$ in Loch Logan at the sampling sites over the study period (June to December 2000). The dotted line indicates the mean values and the solid line the median.

There was a decrease in the Cyanophyta from June to September, but an increase towards December. Microcystis aeruginosa only occurred in December. The Bacillariophyta and Euglenophyta both decreased towards December, whilst the Chlorophyta increased. A few Cryprophyta and Chrysophyta occurred in December. Chlorophyta (Chlorella spp.) and Bacillariophyta (Nitzschia spp.) are the dominant divisions in Loch Logan.

\section{Discussion}

The results showed that most of Loch Logan's nitrate-nitrogen $\left(\mathrm{NO}_{3}-\mathrm{N}\right)$ probably originated from stormwater (the rapid increase of $\mathrm{NO}_{3}-\mathrm{N}$ in September). When heavy rains occurred, there were always storm sewers that overflowed under the water pressure and this sewage-contaminated water also ended up in Loch Logan. Street children and other homeless people deposit trash and other waste into the canal systems and this, together with other organic material like leaves, is flushed into Loch Logan with the stormwater.. The ammonium-nitrogen was probably produced by mineralisation from waste and other organic matter that decomposed (Axler et al., 1996). Decomposition by bac- 
TABLE 4

The average algal composition in Loch Logan (near the dam wall) for June, September and December 2000 (only species that occurred more than $1 \%$ of the total average were listed)

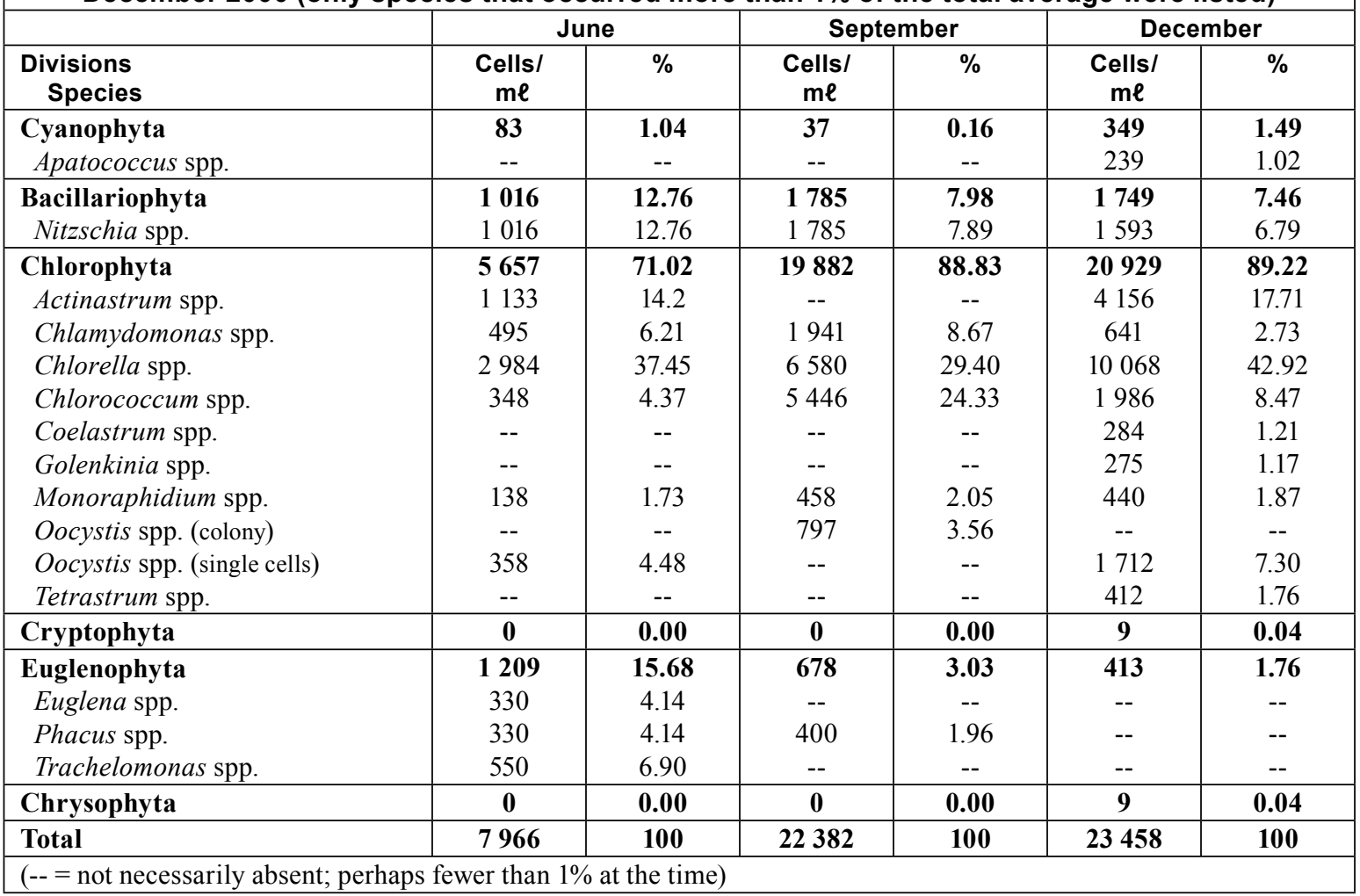

teria consumes a significant amount of oxygen and can cause oxygen depletion in the bottom water. The nitrification of ammonium to nitrate may reduce the ammonium concentrations, but the nitrate is also readily available to algae.

The average $\mathrm{NH}_{4}-\mathrm{N}$ and $\mathrm{NO}_{3}-\mathrm{N}$ concentrations of Loch Logan were 180 and $148 \mu \mathrm{g} / \ell$, respectively. This is in fact much lower than the concentrations of other urban impoundments (mean $\mathrm{NH}_{4}-\mathrm{N}=2.5 \mathrm{mg} / \ell$, mean $\mathrm{NO}_{3}-\mathrm{N}=2.2 \mathrm{mg} / \ell$ ) that have been studied in South Africa (Wiechers et al., 1996). The nitrogen concentrations of North End Lake (1991 to 94) $\left(\mathrm{NH}_{4}-\mathrm{N}\right.$ $\left.=290 \mu \mathrm{g} / \ell ; \mathrm{NO}_{3}-\mathrm{N}=210 \mu \mathrm{g} / \ell\right)$ were the closest to that of Loch Logan (Wiechers et al., 1996).

The mean dissolved inorganic nitrogen concentration ( $\mathrm{DIN}=$ $\mathrm{NO}_{3}-\mathrm{N}+\mathrm{NH}_{4}-\mathrm{N}$ ) for the study period was $318 \mu \mathrm{g} / \ell$, and according to the South African Water Quality Guidelines for Aquatic Ecosystems (DWAF, 1996a) this is in the range of oligotrophic systems. Oligotrophic water has an average summer inorganic nitrogen concentration of less than $500 \mu \mathrm{g} / \ell$. Only the DIN of October and November 2000 were higher than $500 \mu \mathrm{g} / \ell$ due to the spring rain runoff that washed the canal waste into Loch Logan.

The mean $\mathrm{PO}_{4}-\mathrm{P}$ concentration for the study period in Loch Logan was high $(76 \mu \mathrm{g} / \ell)$ and is considered as eutrophic (DWAF, 1996a). The impoundment with the average $\mathrm{PO}_{4}-\mathrm{P}$ concentrations closest to those of Loch Logan's is Zoo Lake (1989 to 94) $(130 \mu \mathrm{g} / \ell)$ (Wiechers et al., 1996). The $\mathrm{PO}_{4}-\mathrm{P}$ concentration of Loch Logan increased during periods that followed a heavy rainstorm. Phosphate does not have a gaseous state (Horne and Goldman, 1994), therefore the high nutrient concentrations emphasise that the runoff water that entered Loch Logan was in fact enriched.

The mean DIN: DIP ratio in Loch Logan was low, 4.3, which indicates nitrogen as the probable growth-limiting nutrient. In general, if the system's N: P ratio is $<10$ (by mass), nitrogen is considered to limit phytoplankton growth (Horne and Goldman, 1994).

Nutrients that are stored in the sediment can be re-introduced into the water-column by internal loading. This occurs primarily under anoxic conditions and with phosphorus release, iron and sulphate both play a role (Charboneau, 1999). The release of phosphorus from sediments is a significant feature of lakes with anoxic hypolimnia (Rippey et al., 1997) as seen in Loch Logan where the low $\mathrm{O}_{2}$ concentration corresponded to the high $\mathrm{PO}_{4}-\mathrm{P}$ concentration during October to December 2000. This internal loading can sustain eutrophic conditions and probably occurs in every eutrophic lake (Cooke et al., 1993a).

The high $\mathrm{O}_{2}$ concentration during the winter could be ascribed to the fact that oxygen is more soluble in colder water than in warmer water and that the metabolic processes (e.g. respiration) of aquatic organisms are slower in winter than in summer and therefore need less oxygen during the winter for biochemical reactions (Horne and Goldman, 1994). The Chl- $a$ concentration was also fairly high during the winter because of photosynthesis and high light penetration (mean Secchi depth of $880 \mathrm{~mm}$; mean turbidity of $10.7 \mathrm{NTU}$ ), which contributes to the $\mathrm{O}_{2}$ concentration. Winter wind also induced $\mathrm{O}_{2}$ transfer from the atmosphere to the water surface.

The $\mathrm{O}_{2}$ concentration and temperature depth profiles of June, September and December also showed clearly that as the water temperature increased towards the summer, the $\mathrm{O}_{2}$ concentration decreased. The very low $\mathrm{O}_{2}$ concentration in the DW bottom layer could be as a result of decomposition and respiration, where bacteria use a lot of $\mathrm{O}_{2}$ for the decomposition of organic material (Horne and Goldman, 1994). Severe $\mathrm{O}_{2}$ depletion may 
result in an accumulation of ammonium, methane, hydrogen sulphide, ferrous and manganous ions and increased rates of phosphorus being released from the sediment (Axler et al., 1996). The release of ammonium and phosphorus from the sediment influences the concentrations already present in the water, which probably explain the high ammonium concentrations in the bottom water of Loch Logan, especially during summer (Figs. 4, 5 $\& 6)$.

The decrease in water temperature from the surface to the bottom, during December (Fig. 7), indicated weak mixing of the water column due to a thermal gradient.

The $\mathrm{pH}$ levels (slightly alkaline) of the surface sampling points in Loch Logan followed a similar seasonal pattern. The bottom sample's $\mathrm{pH}$ (average of 7.52), however, was always about $0.33 \mathrm{pH}$ units lower than that of the surface. This could be explained by the lower $\mathrm{O}_{2}$ concentration at the bottom, together with higher $\mathrm{CO}_{2}$ levels from decomposition, which lowered the $\mathrm{pH}$. According to DWAF (1996b) no health or aesthetic effects are expected in this $\mathrm{pH}$ range. The $\mathrm{pH}$ levels of Loch Logan followed the same trend pattern as that of the $\mathrm{O}_{2}$ concentration. Twenty -four \% $(\mathrm{p}<0.01)$ of the variation in $\mathrm{pH}$ (DW surface water) could be explained by the variation in $\mathrm{O}_{2}$ concentration (Fig. 9). During photosynthesis the algae take up $\mathrm{CO}_{2}$, which lowers carbonic acid in the water and therefore increase the $\mathrm{pH}$.

Loch Logan's pH of 7.85 is comparable with South African impoundments' average $\mathrm{pH}$ of 7.9. Alexander Dam had the lowest $\mathrm{pH}$ average (6.4) and Zeekoeivlei the highest average (8.8) (Wiechers et al., 1996).

In the winter the average total coliforms and E. coli were very low, with only a very low risk in contracting gastrointestinal illness if in full contact with the water (DWAF, 1996b). After the rains the bacterial count increased significantly did the health risk to contract gastrointestinal illness and other health effects associated with contact recreation.

Algal growth, Chl- $a$ concentration and photosynthesis are mainly influenced by temperature, as well as by nutrients and rainfall. When it rained, the algae were washed out of the system and the nutrients into the system, and the algae showed a lag of 2 to 4 weeks to respond to the high nutrient concentrations. Thus, the algal blooms did not peak in the same month as the nutrients peaked (Sept/Oct), but peaked during the following month (Nov).

In Loch Logan there was a higher concentration of average Chl- $a$ at the inflow than at the Wall surface. The inflow receives seepage water from the canal, which is shallow and heats up rapidly, which stimulate algal growth. The light penetration depth, top to bottom, also favoured high algal growth. The mean Secchi-depth was $500 \mathrm{~mm}$ for the summer and the turbidity was 28.5 NTU

The relatively high Chl- $a$ concentration that occurred in the wall bottom sample could be as a result of the high settling rate of algae - it did occur synchronised with the algal blooms at the surface - to the bottom and that they had not yet lost their Chl- $a$. Alternatively it could have been dead leaf material like grass clippings or other fine organic matter that contains Chl- $a$.

With the increase in nutrients and temperature from June to December, the total algae cells per millilitre also increased from 7966 cells $/ \mathrm{m} \ell$ to 23458 cells $/ \mathrm{m} \ell$. The conditions that favour green algae are high light intensity and nutrients as well as intermediate $\mathrm{pH}$ and temperatures (Watson et al., 1997), which correlated with that of Loch Logan and therefore the dominance of chlorophytes, increasing towards December. Although Bacillariophyta (diatoms) prefer water temperatures below $15^{\circ} \mathrm{C}$ (Zhang and Prepas, 1996), they (mostly pennate diatoms) were present throughout the year comprising an average of $9.83 \%$ of the total algae. Other conditions that favour diatoms are wellmixed water columns and relatively high silica and phosphorus concentrations (Zhang and Prepas, 1996). The percentage composition of Bacillariophytes decreased towards the summer, for in summer the other algae, especially the green algae, out-compete them.

Cyanophyta rarely occurred in the winter, but numbers increased after spring. The following conditions are usually favourable for cyanobacterial growth: $\mathrm{pH}$ values around 8.5, water surface temperatures above $25^{\circ} \mathrm{C}$, conductivity below 80 $\mathrm{mS} / \mathrm{m}$, Secchi depth between 25 to $45 \mathrm{~cm}$ (Bowling and Baker, 1996), and a stratified water-column (Zhang and Prepas, 1996). Cyanobacteria also prefer waters with high phosphorus relative to nitrogen. Some species (e.g. Anabaena) can fix their own nitrogen from the atmosphere (Steinberg and Hartmann, 1988), to outcompete the other algae, especially green algae because cyanobacteria have a slower growth rate (Cromar and Fallowfield, 1997). Most of the above-mentioned conditions coincide with Loch Logan's summer conditions, which were a $\mathrm{pH}$ value of 7.9, water surface temperature of 23.8 , conductivity of 15.8 $\mathrm{mS} / \mathrm{m}(102.7 \mathrm{~g} / \ell$ total dissolved salts), a mean Secchi-depth of $746 \mathrm{~mm}$ and a low turbidity of 22.5 NTU. But during December 2000 only Apatococcus spp. and Microcystis aeruginosa occurred in low numbers. However, cyanobacterial blooms occurred during November 1999 (Anabaena spp.) and during February 2000 (Microcystis and Anabaena spp.).

\section{Conclusions}

While algal growth is a function of temperature, light, nutrients and flow, the algal blooms that occurred in Loch Logan were a result of, amongst other factors, high nutrient concentrations during spring and summer, as well as sufficient light penetration into the water column.

Loch Logan is a dynamic system with large variations in its physical, chemical and biological parameters. Because of the high Chl- $a$ and $\mathrm{PO}_{4}-\mathrm{P}$ concentrations it can be classified as a eutrophic system (poor water quality) with nitrogen as the probable limiting nutrient. This makes it ideal for Cyanophyta to cause algal blooms during spring and summer if all conditions (e.g. temperature, light intensity) are favourable. When it rains, the incoming water adds nutrients to the system and it also flushes the system of algae. After such a flush the system restarts its ecological cycles of nutrient availability for the algae to take up and increase in numbers.

The cycle normally starts with the spring rain. High concentrations of organic and inorganic matter are flushed into Loch Logan. The decomposition of organic matter depletes the oxygen causing fish kills. Through microbial decomposition of the organic matter, inorganic $\mathrm{N}$ and $\mathrm{P}$ were released into the system where algae incorporated it into their cells. The suspended matter settles out and improves light penetration and availability. This stimulates an algae bloom during the following weeks and the oxygen levels, produced during photosynthesis, increase again.

Discharges of inorganic and organic compounds from domestic, agricultural and industrial effluents advance eutrophication of receiving waters. These wastewaters cause various pollution effects due to their high nitrogen $(\mathrm{N})$ and phosphorus (P) concentrations, suspended solids, biological oxygen demand $\left(\mathrm{BOD}_{5}\right)$ and chemical oxygen demand (COD).

The loading of nutrients ( $\mathrm{N}$ and $\mathrm{P}$ ) through pollution leads to eutrophication, which accelerates because of human activ- 
ity. Pollution is an undesirable change in the physical, chemical or biological characteristics of air, water, soil, or food that can adversely affect the health, survival or activities of humans or other living organisms (Miller, 2002). Eutrophication - one of the biggest water quality problems worldwide - increases phytoplankton biomass, the major symptom of eutrophication, which leads to decreasing water clarity and oxygen levels in deeper parts. It also results in fish kills and taste and odour become a problem.

Water bodies can reach a point where pollution and algal blooms became a great nuisance, and all that is left is to take drastic steps with rehabilitation and management. Depending on the system, different methods can be used, e.g. phosphorus removal, dilution and flushing, hypolimnetic withdrawal, phosphorus inactivation, sediment oxidation, or sediment removal (Cooke et al., 1993b).

From the study it was clear that the main causes of algal blooms in Loch Logan were the inflow of storm and urban runoff, overflowing of drains into Loch Logan as well as garbage that was being dumped in the canal. After the decomposition of the organic matter, the algae took up the nutrients and multiplied to form a bloom. During such blooms, the oxygen concentrations could have decreased to such low levels that fish kills could occur. The algal blooms also caused bad odours.

\section{Acknowledgements}

We would like to thank the Waterfront management for the opportunity and partial funding to carry out this study, the University of the Free State for the research facilities and the Mangaung Municipality Health Department for the bacteriological analyses.

\section{References}

AXLER R, LARSEN C, TIKKANEN C, McDONALD M, YOKOM S and AAS P (1996) Water quality issues associated with aquaculture: A case study in mine pit lakes. Water Environ. Res. 68 (6) 995-1011.

BOWLING LC and BAKER PD (1996) Major cyanobacterial bloom in the Barwon-Darling River, Australia, in 1991, and underlying limnological conditions. Mar. Freshwater Res. 47 643-657.

CHARBONEAU D (1999) Chemical precipitation and inactivation as a method to reduce internal phosphorus loading in lakes http://horticulture.coafes.umn.edu/vd/h5015/99fpapers/charboneau.htm (accessed in 2004)

COOKE GD, WELCH EB, MARTIN AB, FULMER DG, HYDE JB, and SCHRIEVE GD (1993a) Effectiveness of Al, Ca, and Fe salts for control of internal phosphorus loading in shallow and deep lakes. Hydrobiol. 253 323-335.

COOKE GD, WELCH EB, PETERSON SA and NEWROTH PR (1993b) Restoration and Management of Lakes and Reservoirs $\left(2^{\text {nd }}\right.$ edn.). Lewis Publishers. USA. 548 pp.
CROMAR NJ and FALLOWFIELD HJ (1997) Effect of nutrient loading and retention time on performance of high rate algal ponds. J. Appl. Phycol. 9 301-309.

DEPARTMENT OF WATER AFFAIRS AND FORESTRY (DWAF) (1996a) South African Water Quality Guidelines. Volume 7. Aquatic Environment ( $1^{\text {st }}$ edn.; $1^{\text {st }}$ issue). 159 pp.

DEPARTMENT OF WATER AFFAIRS AND FORESTRY (DWAF) (1996b) South African Water Quality Guidelines. Volume 2. Recreational Use ( $2^{\text {nd }}$ edn.; $1^{\text {st }}$ issue). $88 \mathrm{pp}$.

FREEMAN MJ, HOWARD MR and WIECHERS HNS (2000) The Management of Urban Impoundments in South Africa. Volume 2. Guideline Manual. Water Research Commission Report No. $117 / 2000$.

HORNE AJ and GOLDMAN CR (1994) Limnology (2 ${ }^{\text {nd }}$ edn.). McGraw-Hill, Inc. Singapore. 576 pp.

JENKINS D and MEDSKER LL (1963) Brucine method for determination of nitrate in ocean, estuarine and freshwater. Anal. Chem.. 610-612.

KONING N (1998) Water Quality of the Modder River. Unpublished M.Sc. Thesis. University of the Orange Free State, South Africa. 145 pp.

LEE GF and JONES-LEE A (1993) water quality of stormwater-associated contaminants: Focus on real problems. Condensed version published in: Proc. 1st Int. IWQA Conf. Specialized in Diffuse Pollution: Sources, Prevention, Impact and Abatement. Chicago, IL. 45 pp.

MILLER GT (Jr) (2002) Living in the Environment: Principles, Connections and Solutions $\left(12^{\text {th }}\right.$ edn.). Wadsworth Group. Brooks/Cole. USA. $578 \mathrm{pp}$.

RIPPEY B, ANDERSON NJ and FOY RH (1997) Accuracy of diatominferred total phosphorus concentrations and the accelerated eutrophication of a lake due to reduced flushing and increased internal loading. Can. J. Fish. Aquat. Sci. 54 2637-2646.

SARTORY DP and GROBBELAAR JU (1984) Extraction of chlorophyll- $a$ from freshwater phytoplankton for spectrophotometric analysis. Hydrobiol. 114 177-187.

SA WEATHER SERVICE (2001) http://www.weathersa.co.za (accessed in 2001).

STANDARD METHODS (1995) Standard Methods for the Examination of Water and Waste Water $\left(19^{\text {th }}\right.$ edn.) Eaton AD, Clesceri LS and Greenberg AE (eds.) APHA, AWWA and WEF Washington. pp.4.80-4.81, 4.112-4.113 \& 4.1184.120.

STEINBERG CEW and HARTMANN HM (1988) Planktonic bloomforming cyanobacteria and the eutrophication of lakes and rivers. Freshwater Biol. 20 279-287.

WATSON SB, McCAULEY E and DOWNING JA (1997) Patterns in phytoplankton taxonomic composition across temperate lakes of differing nutrient status. Limnol. Oceanogr. 42 (3) 487-495.

WIECHERS HNS, FREEMAN MJ and HOWARD MR (1996) The Management of Urban Impoundments in South Africa. Volume 1 Status Quo Report. Water Research Commission Report No $77 / 96$.

ZHANG Y and PREPAS EE (1996) Regulation of the dominance of planktonic diatoms and cyanobacteria in four eutrophic hardwater lakes by nutrients, water column stability, and temperature. Can. J. Fish. Aquat. Sci. 53 621-633. 